\title{
VERTICAL DISTRIBUTION OF THE TICK IXODES RICINUS AND TICK-BORNE PATHOGENS IN THE NORTHERN MORAVIAN MOUNTAINS CORRELATED WITH CLIMATE WARMING (JESENÍKY MTS., CZECH REPUBLIC)
}

\author{
Milan Daniel' ${ }^{1}$, Jan Materna ${ }^{2}$, Václav Hönig ${ }^{3,4}$, Ladislav Metelka ${ }^{5}$, Vlasta Danielová1, Josef Harčarik2, Stanislava \\ Kliegrová ${ }^{5}$, Libor Grubhoffer ${ }^{3,4}$ \\ ${ }^{1}$ National Institute of Public Health, Prague, Czech Republic \\ ${ }^{2}$ Krkonoše National Park Authority, Krkonoše Museum, Vrchlabí, Czech Republic \\ ${ }^{3}$ Biology Centre, Institute of Parasitology, Academy of Sciences of the Czech Republic, České Budějovice, Czech Republic \\ ${ }^{4}$ Faculty of Science, University of South Bohemia in České Budějovice, Czech Republic \\ ${ }^{5}$ Czech Hydrometeorological Institute, Hradec Králové, Czech Republic
}

\begin{abstract}
SUMMARY
A study of the vertical distribution of the common tick Ixodes ricinus and tick-borne pathogens - tick-borne encephalitis virus (TBEV) and genospecies of Borrelia burgdorferi s.l. - was performed in the highest part of the Jeseníky mountain area (the Hrubý Jeseník Mts. with the highest summit Praděd, 1,491 m above see level). Altogether 1,253 specimens of all tick stages ( 607 larvae, 614 nymphs, 8 females and 24 males) were collected at the altitude 990-1,300 m above sea level on 12 collection sites by the flagging method. Altogether 1,207 ticks (8 females, 24 males, 568 nymphs and 607 larvae) were examined for the presence of tick-borne encephalitis virus and B. burgdorferi s.l. None of the samples contained TBEV, 35 samples ( $6 \%$ of adult ticks, $5 \%$ of nymphs, $0.7 \%$ of larvae) were positive for $B$. burgdorferi s.l. The most prevalent genospecies were B. afzelii (44\%), B. garinii (28\%), less frequent were B. burgdorferi sensu stricto (5\%), B. valaisiana (3\%). The rather large number of ticks (in absolute numbers as well as recounted to the index: average number of nymphs/worker/collection hour) and the presence of all developmental stages clearly demonstrate that there are viable local tick populations in all the sites, and that recorded ticks were not randomly individuals brought into higher altitudes by birds or game animals. The results are compared with the long-term (2002-2007) monitoring of the tick altitudinal distribution in the Krkonoše Mts. and the conditions, which allow ticks to establish local populations up to the timberline in both mountain areas, are discussed. Simultaneously, changes in climatic conditions (especially the air temperature) monitored at 3 meteorological stations in the area of the Jeseníky Mts. were compared with the records from another 8 stations in other mountain areas in the Czech Republic. A very similar statistically significant trend of increasing mean air temperatures during the last three decades is found at all analyzed stations. The trend is most pronounced in the spring and summer months with the highest activity of I. ricinus ticks.
\end{abstract}

Key words: Ixodes ricinus, Borrelia burgdorferi genospecies, tick-borne encephalitis virus, vertical distribution, climate warming

Address for correspondence: M. Daniel, National Institute of Public Health, Šrobárova 48, 10042 Prague 10, Czech Republic. E-mail: midaniel@seznam.cz

\section{INTRODUCTION}

The problem of the Ixodes ricinus ticks infiltration into higher altitudes in Central Europe became important at the beginning of the 1990s, together with the increasing occurrence of tick-borne infections in new areas. In the Czech Republic, the first such recorded manifestation was the infection by tick-borne encephalitis virus (TBEV) following verified infestation by the tick I. ricinus at an altitude of $900 \mathrm{~m}$ above sea level (a.s.l.) in the Šumava Mts. in 1996 and 2001 (1). Consequently, the investigation of the changes in I. ricinus vertical distribution was first focused on the area of the Šumava Mts. where I. ricinus was recorded at an altitude of 1,020 $\mathrm{m}$ in 2002. The comparison with the historical unpublished field and experimental data concerning the vertical distribution of I. ricinus in these mountains in 1959 and in 1960s (1) confirmed that its vertical distribution limit had considerably changed since that time.

The subsequent investigation was aimed at the highest mountain area in the Czech Republic, the Krkonoše Mts., where detailed historical data (based on the field experiment in 1981-1983) on I. ricinus vertical distribution up to $700-750 \mathrm{~m}$ were available (2, 3). Recently (2002-2007), ticks were regularly recorded up to $1,100 \mathrm{~m}$ and rarely up to $1,270 \mathrm{~m}$ a.s.l. (thus up to the timber line) during regular monitoring of ticks along two vertical transects in the central and eastern parts of the Krkonoše Mts. $(4,5)$ Simultaneously, the TBEV was detected in collected ticks up to 1,140 m (6), borreliae (Borrelia valaisiana) up to 1,270 m (7 and 
unpublished data). The long term (2004-2007) field experiment on the development of individual I. ricinus stages along an altitudinal transect in the central part of the Krkonoše Mts. (650-1,550 $\mathrm{m})$ allowed to correlate the shift in its vertical distribution with general temperature increase in spring and summer periods in the Krkonoše Mts. during the last 5 decades and also with present local microclimatic conditions (5).

The above mentioned results led to the aim to verify the degree of general validity of obtained conclusions in other mountain areas in the Czech Republic, foremost in the Jeseníky Mts. as the second highest mountain range in the Czech Republic after the Krkonoše Mts. Our aim was moreover also supported by the fact that the Northern Moravian Region (particularly the districts Šumperk and Bruntál) has long exhibited a high occurrence of TBE human cases, frequently in localities close to mountain areas. For example, in the 1970-2000 period, TBE cases were recorded sporadically at altitudes above 600 m (localities Lázně Jeseník and Branná) and even at 780 m (Karlova Studánka) (8).

No systematic attention has been yet devoted to ticks in the northern Moravian mountain areas. The former Northern Moravian Region (districts Olomouc, Bruntál, Šumperk and Opava) was represented only by localities at an altitude of 263-390 m in an extensive study of the phenology of $I$. ricinus performed simultaneously in seven regions in Bohemia and Moravia by Černý et al. in 1960-1962 (9). Kašpar (10) studied the occurrence and seasonal dynamics of I. ricinus at 7 northern Moravian localities at an altitude of 260-556 $\mathrm{m}$ in the districts of Olomouc and Opava. He concluded that "ticks were less numerous in the colder locations close to $600 \mathrm{~m}$ and the seasonal dynamic curves differed from the course found at lower altitudes”. Chmela (11) carried out the field experiment concerning the ecology of I. ricinus in the northern Moravian natural focus of TBE in the foothills of the Nízký Jeseník Mts. at an altitude of 325 m. In the same area, Ašmera et al. (12) collected I. ricinus ticks up to 600 m. Rosický (13) mentioned the Jeseníky Mts. (without specification of the locality) as an example of the occurrence of I. ricinus in mountain areas. He found ticks within the study of ectoparasites of small terrestrial mammals and we suppose that tick individuals found were probably confused with Ixodes trianguliceps, which is a specific nest species of small terrestrial mammals, common in submountain and mountain areas. Reliable distinction of immature stages of these two ticks species was published only in 1958 (14) when, however, the material of ticks collected by Rosický from the Jeseníky Mts. was no more available for verification.

We are attempting to fill in the gap in knowledge of the distribution of $I$. ricinus in the highest mountains in Northern Moravia and compare the results obtained with experience gained in the Krkonoše area, especially in relation to climatic conditions and their potential impact on circulation of tick-borne pathogens under natural conditions in these mountains.

\section{MATERIALS AND METHODS}

\section{Study Area}

The investigation was performed in the territory of the Hrubý Jeseník Mts. (with the highest summit Praděd, 1491 m), which is the central and highest part of the Jeseníky Protected Landscape
Area. This is a very cold area (average annual temperature on Praděd Mt. is $0.9^{\circ} \mathrm{C}$ ). Approximately $1,200-1,300 \mathrm{~mm}$ of precipitation falls on the ridges annually and $800-1,000 \mathrm{~mm}$ in the foothills; this is reduced to $700 \mathrm{~mm}$ on the eastern side. The timber line lies at 1,300-1,350 m, above which mountain meadows are situated. A natural dwarf pine zone is not developed and this species has been only artificially planted in some places.

Altogether 12 sites were selected for the tick collection at the altitude 990-1,300 m, both in planted and autochthonous spruce (Picea abies) forest stands. Special attention was paid to the forest edges (ecotones) and to open canopy parts of young forests with dense grass and herb undergrowth, where the probability of occurrence of ticks would be highest. Also good accessibility of the examined sites and the frequency of tourist visits was taken into consideration.

\section{Collection of Host-seeking Ticks}

Ticks were collected by the flagging method in the period 16-20 June 2008, i.e. at the time of the highest expected I. ricinus host-seeking activity. The ground-level temperature during collection at the individual sites varied from 10.6 to $17.9^{\circ} \mathrm{C}$, and the relative air humidity from 64 to 99\%. Flagging was performed simultaneously by four workers at one place for at least one working hour. For comparison of tick density on the individual sites, the numbers of collected ticks were recounted as the average number of ticks (nymphs) per worker / hour (IrN/worker/h) Following species determination, the collected ticks were stored at $-80{ }^{\circ} \mathrm{C}$ for further laboratory examination.

\section{Detection of Tick-borne Encephalitis Virus and Bor- relia burgdorferi s.l.}

Tick samples were prepared by the Chelex method according to Rudenko et al. (15). For the detection of TBEV pools of 10 samples were prepared, for the detection of $B$. burgdorferi s.l. only larvae were pooled nymphs and adults were tested individually.

The final concentrations in the RT-PCR reaction were: $1 \mathrm{x}$ M-MLV reaction buffer (50 mM Tris-HCl ( $\mathrm{pH} 8.3$ ), $75 \mathrm{mM}$ $\mathrm{MgCl}_{2}$ ), $10 \mathrm{mM}$ DTT, $0.5 \mathrm{mM}$ dGTP, $0.5 \mathrm{mM}$ dATP, $0.5 \mathrm{mM}$ dTTP, 0.5 mM dCTP (Top-Bio, Czech Republic); $1 \mu \mathrm{M}$ primer E (R) (CCGTTGGAAGGTGTTCCACT) (Generi-Biotech, Czech Republic); 50 U M-MLV reverse transcriptase (Top-Bio, Czech Republic); 40 U RNase inhibitor (RiboLock, Fermentas) + 8 $\mu \mathrm{l}$ of the sample. The cDNA synthesis was conducted 1 hour at $37^{\circ} \mathrm{C}$. Positive and negative controls were included.

PCR mixture contained: 1x PPP Master Mix (75 mM Tris-HCl, $\mathrm{pH}$ 8,8, $20 \mathrm{mM}\left(\mathrm{NH}_{4}\right)_{2} \mathrm{SO}_{4}, 0.01 \%$ Tween 20, $200 \mu \mathrm{M}$ dATP, 200 $\mu \mathrm{M}$ dCTP, $200 \mu \mathrm{M}$ dGTP, $200 \mu \mathrm{M}$ dTTP, $2.5 \mathrm{U}$ Taq purple DNA

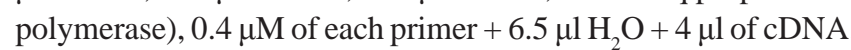
Amplification was conducted as follows: $95^{\circ} \mathrm{C} 5 \mathrm{~min}$. followed by 30 cycles of $94^{\circ} \mathrm{C} 30 \mathrm{~s}, 55^{\circ} \mathrm{C}\left(50^{\circ} \mathrm{C}\right.$ for EF/ER primer pair, $52{ }^{\circ} \mathrm{C}$ for P8/P9), $1 \mathrm{~min} .72{ }^{\circ} \mathrm{C}$ followed by final extension at $72{ }^{\circ} \mathrm{C} 5 \mathrm{~min}$. Positive and negative controls were included.

For the detection of TBEV primer pair EF (GGGGACYACGAGGGTYACCT), ER (CCGTTGGAAGGTGTTCCACT) was used. Borrelia burgdorferi sensu lato was detected by the primer pair SL1, SL2 (16). Positive samples were subjected to genospecies-specific PCR according to Demaerschalck et al. (16). For the detection of $B$. valaisiana primers P8, P9 were used (17). 
Table 1. Vertical distribution of Ixodes ricinus tick in the Hrubý Jeseník Mts

\begin{tabular}{|c|c|c|c|c|c|c|c|c|c|}
\hline \multirow{2}{*}{ Locality } & \multirow{2}{*}{ Habitat } & \multirow{2}{*}{ Coordinates } & \multirow{2}{*}{ Altitude $\mathrm{m}$ a.s.l. } & \multirow{2}{*}{ Date of collection } & \multicolumn{4}{|c|}{ Number of collected ticks* } & \multirow{2}{*}{$\begin{array}{c}\text { IrN/ } \\
\text { worker/h** }\end{array}$} \\
\hline & & & & & L & $\mathrm{N}$ & $\mathrm{F}$ & $M$ & \\
\hline $\begin{array}{l}\text { Červenohorské } \\
\text { sedlo I }\end{array}$ & $\begin{array}{l}\text { forest edges } \\
\text { along ski pistes }\end{array}$ & $\begin{array}{l}50^{\circ} 07^{\prime} 52^{\prime \prime} \mathrm{N} \\
17^{\circ} 09^{\prime} 32^{\prime \prime} \mathrm{E}\end{array}$ & 990 & 18.6.2008 & 42 & 75 & 0 & 0 & 25.0 \\
\hline $\begin{array}{l}\text { Červenohorské } \\
\text { sedlo II }\end{array}$ & $\begin{array}{l}\text { forest edge along } \\
\text { footpath }\end{array}$ & $\begin{array}{l}50^{\circ} 07^{\prime} 52^{\prime \prime} \mathrm{N} \\
17^{\circ} 09^{\prime} 32^{\prime \prime} \mathrm{E}\end{array}$ & $1,040-1,050$ & 18.6.2008 & 122 & 40 & 0 & 2 & 13.3 \\
\hline $\begin{array}{l}\text { Červenohorské } \\
\text { sedlo III }\end{array}$ & $\begin{array}{l}\text { young spruce } \\
\text { forest }\end{array}$ & $\begin{array}{l}50^{\circ} 07^{\prime} 52^{\prime \prime N} \\
17^{\circ} 09^{\prime} 32 " \mathrm{E}\end{array}$ & $1,020-1,040$ & 18.6.2008 & 68 & 53 & 1 & 1 & 10.4 \\
\hline $\begin{array}{l}\text { Vidly - Karlova } \\
\text { Studánka }\end{array}$ & $\begin{array}{l}\text { edge of young } \\
\text { spruce forest }\end{array}$ & $\begin{array}{l}50^{\circ} 05^{\prime} 00^{\prime \prime} \mathrm{N} \\
17^{\circ} 17^{\prime} 42^{\prime \prime} \mathrm{E}\end{array}$ & 1,004 & 17.6 .2008 & 0 & 78 & 4 & 6 & 13.0 \\
\hline Volská louka & $\begin{array}{l}\text { edge of young } \\
\text { spruce forest }\end{array}$ & $\begin{array}{l}50^{\circ} 09^{\prime} 35^{\prime \prime} \mathrm{N} \\
17^{\circ} 04^{\prime} 45^{\prime \prime} \mathrm{E}\end{array}$ & $1,000-1,010$ & 18.6.2008 & 26 & 86 & 1 & 3 & 21.5 \\
\hline Videlské sedlo & $\begin{array}{l}\text { edge of young } \\
\text { spruce forest }\end{array}$ & $\begin{array}{l}50^{\circ} 07^{\prime} 27^{\prime \prime} \mathrm{N} \\
17^{\circ} 14^{\prime} 58^{\prime \prime} \mathrm{E}\end{array}$ & 1,007 & 19.6.2008 & 76 & 98 & 0 & 3 & 19.6 \\
\hline $\begin{array}{l}\text { Orlík Mt. } \\
\text { (Kristovo loučení) }\end{array}$ & $\begin{array}{l}\text { forest edge along } \\
\text { footpath }\end{array}$ & $\begin{array}{l}50^{\circ} 10^{\prime} 34^{\prime \prime} \mathrm{N} \\
17^{\circ} 17^{\prime} 24^{\prime \prime} \mathrm{E}\end{array}$ & 1,054 & 19.6.2008 & 1 & 12 & 0 & 0 & 3.0 \\
\hline $\begin{array}{l}\text { Černý vrch Mt. } \\
\text { southern slope }\end{array}$ & $\begin{array}{l}\text { young open } \\
\text { spruce forest }\end{array}$ & $\begin{array}{l}50^{\circ} 08^{\prime} 27^{\prime \prime} \mathrm{N} \\
17^{\circ} 16^{\prime} 36^{\prime \prime} \mathrm{E}\end{array}$ & $1,140-1,150$ & 19.6.2008 & 159 & 97 & 0 & 3 & 24.3 \\
\hline $\begin{array}{l}\text { Kamzičí vrch Mt. } \\
\text { - southern slope I }\end{array}$ & $\begin{array}{l}\text { old autochthonous } \\
\text { mixed forest }\end{array}$ & $\begin{array}{l}50^{\circ} 05^{\prime} 53^{\prime \prime} \mathrm{N} \\
17^{\circ} 14^{\prime} 54^{\prime \prime} \mathrm{E}\end{array}$ & $1,070-1,100$ & 19.6.2008 & 0 & 17 & 0 & 3 & 8.5 \\
\hline $\begin{array}{l}\text { Kamzičí vrch Mt. } \\
\text { - southern slope II }\end{array}$ & $\begin{array}{l}\text { young open } \\
\text { spruce forest }\end{array}$ & $\begin{array}{l}50^{\circ} 05^{\prime} 53^{\prime \prime} \mathrm{N} \\
17^{\circ} 14^{\prime} 54^{\prime \prime} \mathrm{E}\end{array}$ & $1,070-1,100$ & 19.6.2008 & 30 & 55 & 2 & 3 & 27.5 \\
\hline $\begin{array}{l}\text { Vysoká hole Mt. } \\
\text { - eastern slope }\end{array}$ & $\begin{array}{l}\text { spruce groups on } \\
\text { alpine medows }\end{array}$ & $\begin{array}{l}50^{\circ} 03^{\prime} 43^{\prime \prime} \mathrm{N} \\
17^{\circ} 14^{\prime} 49^{\prime \prime} \mathrm{E}\end{array}$ & 1,300 & 20.6 .2008 & 83 & 3 & 0 & 0 & 1.5 \\
\hline $\begin{array}{l}\text { Vysoká hole Mt. } \\
\text { - north- eastern } \\
\text { slope }\end{array}$ & $\begin{array}{l}\text { solitary old } \\
\text { spruces at timber } \\
\text { line }\end{array}$ & $\begin{array}{l}50^{\circ} 03^{\prime} 43^{\prime \prime} \mathrm{N} \\
17^{\circ} 14^{\prime} 49^{\prime \prime} \mathrm{E}\end{array}$ & $1,350-1,370$ & 20.6 .2008 & 0 & 0 & 0 & 0 & 0.0 \\
\hline Total & & & & & 607 & 614 & 8 & 24 & \\
\hline
\end{tabular}

* $\quad \mathrm{L}$ - larvae; $\mathrm{N}$ - nymphs; $\mathrm{F}$ - females; $\mathrm{M}$ - males;

** Average number of nymphs per 1 worker per 1 hour

Analysis of Climate Development in the Jeseníky Mts. (1979-2007) and its Comparison with other Czech and Moravian Mountains

Long-term meteorological data (1979-2007) from 2 meteorological stations of the Czech Hydrometeorological Institute (CHMI) from the Jeseníky Mts. (Karlova Studánka [5004’23”N, $17^{\circ} 18^{\prime} 21^{\prime}$ E, $780 \mathrm{~m}$ ], Praděd [ $50^{\circ} 04^{\prime} 58^{\prime \prime} \mathrm{N}, 17^{\circ} 13^{\prime} 48^{\prime} \mathrm{E}, 1490 \mathrm{~m}$ - measurements were terminated in 1997]) and one from their foothills (Staré Město pod Sněžníkem [50¹1'34”N, 1656'31”E, $658 \mathrm{~m}]$ ) were analysed to gain the information about climate development (air temperature, precipitation) in the studied area.

To compare and generalize the results regarding climate development and I. ricinus vertical distribution in the Jeseníky Mts. and the Krkonoše Mts. (5) data (1979-2007) from another 8 meteorological stations from 7 Czech and Moravian mountain areas were included in the analysis: the Beskydy Mts. (Lysá hora [49³2'46”N $18^{\circ} 26^{\prime} 52^{\prime}$ E, $\left.1322 \mathrm{~m}\right]$ ]), the Orlické hory Mts. (Rokytnice v Orlických horách [5009’52”N, 16²7’37’E, $572 \mathrm{~m}]$ ), the Krkonoše Mts. (Labská bouda [5045’39”N,

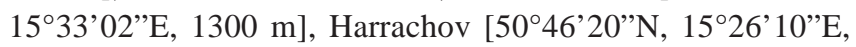
$670 \mathrm{~m}]$ ), the České středohoří Highland (Milešovka [50³3'17”N, $\left.13^{\circ} 55^{\prime} 53^{\prime} \mathrm{E}, 837 \mathrm{~m}\right]$ ), the Šumava Mts. (Churáňov [4904’06”N, 13³6’54”E, $1118 \mathrm{~m}$ ], the Český Les Mts. (Přimda [4940’10”N, $12^{\circ} 40^{\prime} 41^{\prime \prime}$, $\left.742 \mathrm{~m}\right]$ ) and the Českomoravská vysočina Highland (Svratouch [ $\left.49^{\circ} 44^{\prime} 06^{\prime \prime} \mathrm{N}, 16^{\circ} 02^{\prime} 01^{\prime} \mathrm{E}, 737 \mathrm{~m}\right]$ ). Five professional stations of the CHMI (Churáňov, Svratouch, Přimda, Lysá hora, Praděd), 1 professional station of the Institute of Atmospheric Physics (Milešovka) and 5 meteorological stations of the CHMI (Labská bouda, Rokytnice v Orlických horách, Harrachov, Karlova Studánka a Staré Město pod Sněžníkem) were included. The missing data at each station were before processing filled in on a monthly principle. Monthly, seasonal and annual temperatures and amount of precipitations were then calculated for filled series of observations. Verified data were evaluated by STATISTICA 7 software (www.statistica.com).

\section{RESULTS}

\section{Vertical Distribution of Ixodes ricinus}

In the altitude $990-1,300 \mathrm{~m}$, altogether 1,253 specimens of all I. ricinus stages (607 larvae, 614 nymphs, 8 females and 24 males) were collected (Table 1). The relatively high number of ticks (in absolute numbers as well as recounted to the comparative index $I r \mathrm{~N} /$ worker/h) and the presence of all developmental stages clearly 
demonstrated that there are local tick populations at all investigated sites, and that recorded ticks were not individuals randomly brought into higher altitudes by birds or game animals.

A particular attention was paid to the area of the saddle Červenohorské sedlo, which is well-known sport and tourist resort because of the easy access by car and public transport and as a starting point for many marked tourist paths. Typical habitats were investigated at altitudes $990-1,050 \mathrm{~m}$ at this locality: edges of the spruce forest aisles created for ski pistes, edges of marked footpath; young open canopy spruce plantations and young mixed (Salix caprea, Sorbus aucuparius, Fagus sylvatica) forest stands (all with dense herb undergrowth). The edges of the ski pistes with substantially altered soil surface (piled-up mounds of soil) covered by very dense herb vegetation showed the twice more abundant tick populations (25 $\operatorname{IrN} /$ worker/h) than the other habitats (10.4-13.3 IrN/worker/h).

The comparison of tick densities between old autochthonous mixed forest and adjacent young planted spruce forest stands on the southern slope of the Kamzičí vrch Mt. (1,070-1,100 m) brought very interesting results. Whereas tick density in an open canopy old beech and spruce mixed forest stand with well-developed herbaceous layer reached $8.5 \mathrm{IrN} /$ worker/h, it was 27.5 IrN/worker/h in planted open canopy young spruce stand, also with well developed herbaceous layer. This example is in agreement with the general results of our observation, that the tick I. ricinus was most abundant in open canopy young spruce forests with rich herbaceous undergrowth, especially along their edges (ecotones) (Table 1).

The highest finding of $I$. ricinus at an altitude of $1,300 \mathrm{~m}$ in a mosaic of groups of spruce trees and alpine meadows close to the timber line was recorded on the slope of the Vysoká hole Mt. (Table 1). It should be emphasized that, in addition to nymphs, a considerable number of larvae were collected at this habitat. It indicates that the whole tick developmental cycle have to proceed there.

\section{Tick-borne Encephalitis Virus and Borrelia burgdor- feri s.l. Investigation}

A total of 1,207 ticks ( 8 females, 24 males, 568 nymphs and 607 larvae) were examined for the presence of tick-borne encephalitis virus and Borrelia burgdorferi s.l. All the samples were negative for TBEV, 35 samples (including four pools of larvae) were positive for B. burgdorferi s.l. The prevalence rate reached $6.3 \%$ in adults (2 positive/32 examined), 5.1\% for nymphs (29/541) and the minimum infection rate in larvae reached $0.7 \%(4 / 607)$. The results are summarized in Table 2.

The genospecies of B. burgdorferi s.l. were identified by means of species-specific PCR. B. afzelii and B. garinii were the most frequently detected species (43.6 \% and $28.2 \%$ respectively), B. burgdorferi s.s. (5.1\%) and B. valaisiana (2.5\%) were less frequent. A relatively high portion (20.5\%) of positive samples was not identified as one of the above mentioned species. Co-infection with B. afzelii and B. garinii occurred in 4 samples.

Ticks positive for borreliae were found in samples from all the localities through the whole range of the altitudes (990-1,300 m). All samples positive for $B$. garinii except of one were collected at altitudes above $1,040 \mathrm{~m}$ whereas 12 of 17 samples positive for B. afzelii originated from altitudes not higher than $1,010 \mathrm{~m}$.

Climate Development in the Jeseníky Mts. (19792007) and its Comparison with Other Czech and Moravian Mountains

A statistically significant rise in the mean annual air temperature by $0.5^{\circ} \mathrm{C} / 10$ years was recorded at all analysed stations from

Table 2. Borrelia burgdorferi genospecies in Ixodes ricinus ticks in Hrubý Jeseník Mts

\begin{tabular}{|c|c|c|c|c|c|c|c|}
\hline Locality & $\begin{array}{l}\text { Altitude m } \\
\text { a.s.l. }\end{array}$ & $\begin{array}{l}\text { Adults posi- } \\
\text { tivelexam. }\end{array}$ & $\begin{array}{l}\text { B. burgdorferi } \\
\text { genospecies }\end{array}$ & $\begin{array}{c}\text { Nymphs positivel } \\
\text { exam. (prevalence } \\
\text { rate) }\end{array}$ & $\begin{array}{l}\text { B. burgdorferi } \\
\text { genospecies }\end{array}$ & $\begin{array}{l}\text { Larvae positivel } \\
\text { exam. (preva- } \\
\text { lence rate) }\end{array}$ & $\begin{array}{l}\text { B. burgdorferi } \\
\text { genospecies }\end{array}$ \\
\hline \multirow{3}{*}{$\begin{array}{l}\text { Červenohorské } \\
\text { sedlo }\end{array}$} & 990 & $0 / 0$ & & $2 / 66(3.0 \%)$ & $\begin{array}{l}1 \text { B. afzelii } \\
1 \text { undetermined }\end{array}$ & 0/42 & \\
\hline & $1,040-1,050$ & $0 / 2$ & & $2 / 42(4.8 \%)$ & $\begin{array}{l}1 \text { B. garinii } \\
1 \text { undetermined }\end{array}$ & $1 / 122(0.8 \%)$ & B. burgdorferi s.s. \\
\hline & $1,020-1,040$ & $0 / 2$ & & $1 / 49(2.0 \%)$ & B. afzelii & $1 / 68(1.5 \%)$ & B. valasiana \\
\hline $\begin{array}{l}\text { Vidly - Karlova } \\
\text { Studánka }\end{array}$ & 1,004 & $0 / 10$ & & $2 / 71(2.8 \%)$ & $\begin{array}{l}1 \text { B. afzelii } \\
1 \text { undetermined }\end{array}$ & $0 / 0$ & \\
\hline Volská louka & $1,000-1,010$ & $0 / 4$ & & $7 / 80(8.8 \%)$ & $\begin{array}{l}3 \text { B. afzelii } \\
4 \text { undetermined }\end{array}$ & $0 / 26$ & \\
\hline Videlské sedlo & 1,007 & $1 / 3$ & B. afzelii & $6 / 90(6.7 \%)$ & $\begin{array}{l}5 \text { B. afzelii } \\
1 \text { B. afzelii + garinii }\end{array}$ & $0 / 76$ & \\
\hline Sedlo Orlíku & 1,054 & $0 / 0$ & & $0 / 12(0.0 \%)$ & & $0 / 1$ & \\
\hline Černý vrch & $1,140-1,150$ & $0 / 3$ & & $4 / 63(6.3 \%)$ & $\begin{array}{l}1 \text { B. afzelii } \\
1 \text { B. garinii } \\
1 \text { B. afzelii + garinii } \\
1 \text { undetermined }\end{array}$ & $1 / 159(0.6 \%)$ & B. garinii \\
\hline Kamzičí vrch & $1,070-1,100$ & $1 / 8$ & B. garinii & $4 / 65(7.7 \%)$ & $\begin{array}{l}2 \text { B. garinii } \\
2 \text { B afzelii + garinii }\end{array}$ & $0 / 30$ & \\
\hline Vysoká hole & 1,300 & $0 / 0$ & & $1 / 3(33.3 \%)$ & B. burgdorferi s.s. & $1 / 83(1.2 \%)$ & B. garinii \\
\hline Total & $990-1,300$ & 2/32 (6.3\%) & & 29/541 (5.4\%) & & $4 / 607(0.7 \%)$ & \\
\hline
\end{tabular}


Table 3. Linear trends ( ${ }^{\circ} \mathrm{C} / 10$ years) of annual and seasonal mean air temperature courses for the period 1979-2007 at 11 selected meteorological stations from different mountain areas of the Czech republic and its statistical significance

\begin{tabular}{|c|c|c|c|c|c|c|c|c|c|}
\hline \multirow[b]{2}{*}{ Rokytnice v Orlických horách } & \multirow{2}{*}{$\begin{array}{c}\text { Altitude (m a.s.l.) } \\
564\end{array}$} & \multicolumn{2}{|c|}{ Year } & \multicolumn{2}{|c|}{ Spring (III.-V.) } & \multicolumn{2}{|c|}{$\begin{array}{l}\text { Summer } \\
\text { (VI.-VIII.) }\end{array}$} & Autumn (IX.-XI.) & Winter (XII.-II. \\
\hline & & +0.34 & * & +0.28 & & +0.56 & & +0.30 & +0.14 \\
\hline Staré Město pod Smrkem & 658 & +0.49 & ** & +0.42 & & +0.88 & ** & +0.42 & +0.14 \\
\hline Harrachov & 670 & +0.45 & ** & +0.36 & & +0.68 & $\star *$ & +0.38 & +0.29 \\
\hline Svratouch & 737 & +0.49 & ** & +0.51 & * & +0.76 & ** & +0.37 & +0.22 \\
\hline Přimda & 742 & +0.57 & ** & +0.62 & ** & +0.77 & ** & +0.39 & +0.44 \\
\hline Karlova Studánka & 775 & +0.38 & * & +0.37 & & +0.54 & ** & +0.24 & +0.32 \\
\hline Milešovka & 833 & +0.52 & ** & +0.58 & * & +0.75 & ** & +0.33 & +0.34 \\
\hline Churáňov & 1,118 & +0.55 & ** & +0.59 & * & +0.74 & ** & +0.36 & +0.41 \\
\hline Labská Bouda & 1,315 & +0.56 & * & +0.51 & * & +0.73 & * & +0.44 & +0.60 \\
\hline Lysá hora & 1,322 & +0.51 & ** & +0.47 & & +0.83 & $\star *$ & +0.37 & +0.28 \\
\hline Praděd & 1,490 & +0.48 & ** & +0.39 & & +0.68 & $* *$ & +0.39 & +0.36 \\
\hline
\end{tabular}

** - significant at the $1 \%$ level, * - significant at the $5 \%$ level

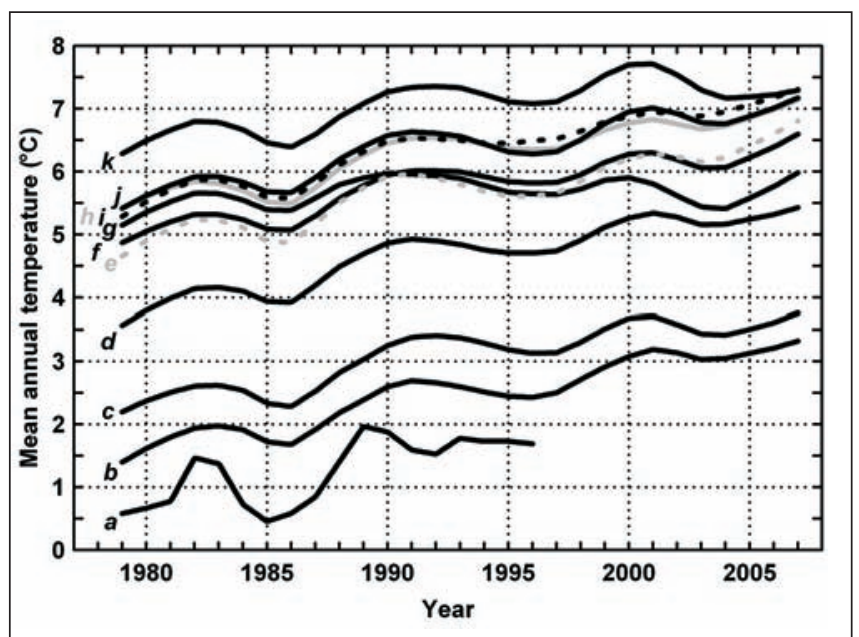

Fig. 1. The mean annual air temperatures $1979-2007$ at 11 selected meteorological stations from different mountain areas of the Czech Republic: a - Praděd, b-Labská bouda, c - Lysá hora, $d$-Churáňov, e (gray dashed curve) - Milešovka, $f$ - Harrachov, g - Karlova Studánka, $h$ (gray curve) - Svratouch, $i$ - (black dashed curve) - Přimda, j- Staré Město pod Sněžníkem, $k$ - Rokytnice $v$ Orlických horách. The values were smoothed by robust locally weighted regression. For meteorological station details see Materials and methods and Table 2.

1979 to 2007 (Table 3). The trend of increasing annual temperature is parallel for all the stations (Fig. 1). The warming differs among individual seasons. The most obvious and statistically significant trends in increasing air temperature were observed at half of evaluated stations in spring $\left(0.5-0.6{ }^{\circ} \mathrm{C} / 10\right.$ years $)$ and at all the stations except one in summer $\left(0.5-0.9^{\circ} \mathrm{C} / 10\right.$ years $)$. The trends are not significant in autumn and winter. The course of seasonal temperatures is similar at all studied stations (Fig. 2, 3)

Fluctuations of the average amount of precipitation are without any long-term trend, but data sets reveal similar course at all stations during 1979-2007. Linear trends of precipitation amounts were not calculated because of considerable year-to-

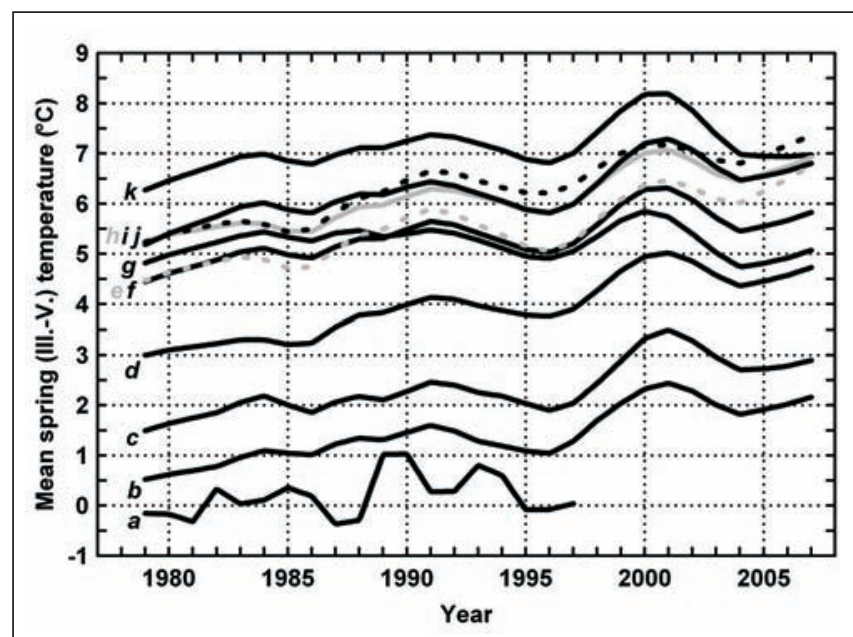

Fig. 2. The mean spring (March-May) air temperatures 1979-2007 at 11 selected meteorological stations from different mountain areas of the Czech Republic. The values were smoothed by robust locally weighted regression. For the legend see Fig. 1.

year variability and weak trend component. Large inter-annual variability without long-term trend is dominant also for seasonal precipitation amounts.

\section{DISCUSSION}

The assumption that the change in the vertical distribution of I. ricinus ticks observed in the Krkonoše Mts. has more general validity was confirmed. The present $I$. ricinus altitudinal distribution limit up to the timber line (approximately 1,250 m) in the 


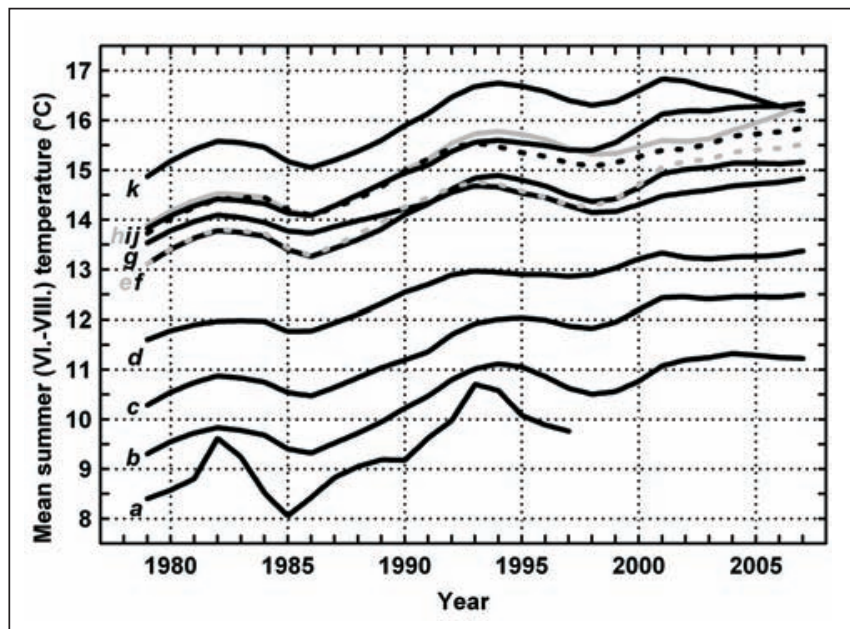

Fig. 3. The mean summer (June-August) air temperatures 1979-2007 at 11 selected meteorological stations from different mountain areas of the Czech Republic. The values were smoothed by robust locally weighted regression. For the legend see Fig. 1.

Krkonoše Mts. (5) was verified in the present study in the Hrubý Jeseník Mts. Comparison of the climatic conditions development in 1997-2007 (Fig. 1-3) and linear temperature trends (Table 3) recorded in the Krkonoše Mts. and those observed in other Czech mountain areas, including the Jeseníky Mts., can be used for evaluating the factors which have enabled shift in I. ricinus vertical distribution. The trends in climate development and obvious warming in spring and mainly summer seasons in past twenty years are very similar in all the mountain areas. It indicates the prevailing influence of large-scale processes on climate warming in the individual mountain areas of the Czech Republic.

If the observed linear trends in the mountain areas are compared with the published values on global warming in the Czech Republic as a whole, an average temperature increase over the past 100 years is $0.74{ }^{\circ} \mathrm{C}(18)$ (while the increase recorded over the past 240 years at the Prague Klementinum station is only $0.8^{\circ} \mathrm{C}$ ), it is obvious that the temperature increase is clearly higher at mountain areas. The observed warming in spring and summer seasons, in the period of high tick activity, forms suitable conditions for I. ricinus shift into higher altitudes in all the mountain areas in the Czech Republic.

The high occurrence of I. ricinus found in the Hrubý Jeseník Mts. at the altitude of 1,000 m upwards is noteworthy, not only in the total number of collected specimens, but especially in the density of local populations expressed as the index IrN/worker/h (Table 1). These data are compared with those recorded during long-term monitoring (2002-2007) at similar altitudes in the Krkonoše Mts. in May to July period. The values from the Krkonoše Mts. (maximum value of 5 nymphs/worker/hour in the central part and 16.3 nymphs/worker/hour in the eastern part) did not attain the values in the Hrubý Jeseník Mts. Two control collections in the Krkonoše Mts. in June 2008, i.e. at the same time of the research in the Hrubý Jeseník Mts., are much closer (21.3 $\mathrm{IrN} /$ worker/h at 980-1,040 m and 14.3 $\mathrm{IrN} /$ worker/h at 1,040-1,050 m) to the values from the Hrubý Jeseník Mts.
Suitable climatic factors are an important, but not the only one factor conditioned the existence of tick local populations. However the entire biocenosis, of which ticks are an integral part, changes in dependence on modifications in the climate; this includes also the tick animal hosts and the vegetation cover, which have another crucial influence on the existence of tick populations. The differences in these conditions are evident when the Krkonoše results are compared on vertical transects in the central part and in the eastern part of the mountains $(4,5)$. Without detailed botanical analysis, it is thus possible to accept the hypothesis that the differences in the vegetation conditions in the Hrubý Jeseník Mts. and the Krkonoše Mts. could form the basis for the higher occurrence of I. ricinus. We suppose that higher situated timber line (for approximately $100 \mathrm{~m}$ compared with the Krkonoše Mts.) and missing dwarf pine zone (montane spruce forest zone is directly followed by alpine meadows) in the Hrubý Jeseník Mts. may substantially influence abundance of $I$. ricinus hosts species (especially small mammals as host for tick larvae and nymphs), which may led to higher tick density observed in the Hrubý Jeseník Mts. compared with those from the Krkonoše Mts. As far as the principal hosts of adult ticks $I$. ricinus are concerned, the recent population of hoofed game in the Landscape Protected Area Jeseníky $\left(740 \mathrm{~km}^{2}\right.$ ) has been regulated significantly in accordance with the local ecosystem since 1993. An extremely high number of red deer was lowered from 1,514 to 1,044 animals between 1994 and 2000. Simultaneously, roe deer were reduced from 2,182 to 1,811 animals. A five degree scale (19) indicates the contemporary size of red deer to be high (5), that of roe deer being well-balanced (4), and that of wild boars to be low (3).

Concerning the tick-borne pathogens in ticks, no TBEV-positive tick was detected. Data from other mountain areas of Czech Republic show that TBEV can be present in ticks as high as 1,140 $\mathrm{m}$ (6). Nevertheless the prevalence of TBEV in ticks may be very low and therefore we can not fully exclude the possibility of its presence in the studied area. Ticks positive for borreliae were found in samples from all the collection sites except of one, where the total number of ticks was very low $(n=13)$. The prevalence of B. burgdorferi s.l. was found to be lower than the European average $-10.8 \%$ in nymphs and $17.4 \%$ in adults (20). B. burgdorferi positive ticks were found as high as $1,300 \mathrm{~m}$. Previously borrelia-positive tick was reported at an altitude of $1,270 \mathrm{~m}$ in the Czech Republic (7). Borreliae were detected in the pools of larvae indicating transovarial transmission. Borrelia-positive larvae were previously reported also by other authors (e.g. 21).

The dominance of B. afzelii and B. garinii among the positive samples is concordant with the data collected throughout Europe (20). The portion of B. burgdorferi s. s. is slightly lower but according to the review (20) the prevalence of this genospecies is declining towards the east in Europe. High number of unidentified positive samples can be explained by the presence of other genospecies than detected. Our study focused on the main pathogenic genospecies. Interestingly, the distribution of $B$. garinii and B. afzelii was not equal throughout the altitudinal gradient. B. afzelii prevailed in samples collected at lower altitudes (900 $1,010 \mathrm{~m}$ ), whereas B. garinii clearly dominated at higher altitudes (1,040-1,300 m). As B. garinii is known to be associated mainly with birds as hosts (22) this finding could indicate an important role of birds as hosts of ticks and source of borreliae at higher 
altitudes. This conclusion as well as the findings concerning the $B$. burgdorferi genospecies distribution is similar to that found in the Krkonoše Mts. $(6,23)$.

In conclusion, it should be emphasized that the most numerous populations of $I$. ricinus ticks were found in young spruce planted stands predominantly at their edges with dense herbaceous undergrowth along foot and biking forest paths, picnic and resting places, frequently visited by visitors of the Jeseníky Landscape Protected area. It emphasizes the necessity of further public education of holidaymakers and nature visitors, leading to effective prevention of tick-borne diseases.

\section{Acknowledgements}

This study was funded by the project of the Czech Science Foundation GACR no. 310/06/1546. The laboratory investigations was also supported by MSM 6007665801 and LC 06009 projects from the Ministry of Education of the Czech Republic, and by the research project Z60220518 of the Institute of Parasitology BC AS CR.

\section{REFERENCES}

1. Daniel M, Danielová V, Kříž B, Jirsa A, Nožička J. Shift of the tick Ixodes ricinus and tick-borne encephalitis to higher altitudes in Central Europe. Eur J Clin Microbiol Infect Dis. 2003 May;22(5):327-8.

2. Daniel M. Influence of the microclimate on the vertical distribution of the tick Ixodes ricinus (L.) in Central Europe. Acarologia. 1993;34:10513.

3. Daniel M, Černý V, Albrecht V, Honzáková E. The microclimate at different altitudes of the Krkonoše Mountains and its effect on the existence of the tick Ixodes ricinus (L.). Opera Corcontica. 1988;25:76-110. (In Czech.)

4. Materna J, Daniel M, Danielová V. Altitudinal distribution limit of the tick Ixodes ricinus shifted considerably towards higher altitudes in Central Europe: results of three years monitoring in the Krkonoše Mts. (Czech Republic). Cent Eur J Public Health. 2005 Mar;13(1):24-8.

5. Materna J, Daniel M, Metelka L, Harčarik J. The vertical distribution, density and the development of the tick Ixodes ricinus in mountain areas influenced by climate changes (The Krkonoše Mts., Czech Republic). Int J Med Microbiol. 2008 Sep;298 Suppl 44:25-37.

6. Danielová V, Schwarzová L, Materna J, Daniel M, Metelka L, Holubová $\mathrm{J}$, et al. Tick-borne encephalitis virus expansion to higher altitudes correlated with climate warming. Int J Med Microbiol. 2008 Sep;298 Suppl 44:68-72.

7. Danielová V, Rudenko N, Daniel M, Holubová J, Materna J, Golovchenko $\mathrm{M}$, et al. Extension of Ixodes ricinus ticks and agents of tick-borne diseases to mountain areas in the Czech Republic. Int J Med Microbiol. 2006 May;296 Suppl 40:48-53.

8. Daniel M, Kříž B. Tick-borne encephalitis in the Czech Republic” I. Predictive maps of Ixodes ricinus tick high-occurrence habitats and a tick-borne encephalitis risk assessment in the Czech regions; II. Maps of tick-borne encephalitis incidence in the Czech Republic in 1971 - 2000. Project Climate Change and Adaptation Strategie for Human Health in Europe (cCASHh), EVK2-2000-00670. Prague: National Institute of Public Health; 2002.
9. Černý V, Rosický B, Ašmera J, Kadlčík K, Kobík V, Kratochvílová E, et al. Results of investigations of phenology of the common tick Ixodes ricinus (L.) in the Czech lands in the years 1960 - 1962. Čs Parasitol. 1965;12(2):125-31. (In Czech.)

10. Kašpar H. Occurrence and seasonal dynamics of the common tick in some North Moravian localities. Acta Univ Agricult Brno. 1964;12(1):83-131. (In Czech.)

11. Chmela J. On the developmental cycle of the common tick (Ixodes ricinus L.) in the North-Moravian natural focus of tick-borne encephalitis. Folia Parasitol. 1969;16:313-19.

12. Ašmera J, Heinz F, Mlýnková H, Opravil E, Šeděnka B, Kupec V. Up-to-date results of research on natural foci of tick encephalitis in the North Moravian Region. Českoslov Epidemiol Mikrobiol Imunol. 1969;18(4):205-17. (In Czech.)

13. Rosický B. Notes on ecology of the tick Ixodes ricinus L. in Central Europe with respect to natural foci. Věst Českoslov Spol Zool. 1954;18:4170. (In Czech.)

14. Černý V. Key to identification of tick larvae and nymphs parasitizing on small mammals. Českoslov Epidemiol Mikrobiol Imunol. 1958;7(2):1368. (In Czech.)

15. Rudenko N, Golovchenko M, Cihlářová V, Grubhoffer L. Tick-borne encephalitis virus-specific RT-PCR - a rapid test for detection of the pathogen without viral RNA purification. Acta Virol. 2004;48(3):16771.

16. Demaerschalck I, Ben Messaoud A, De Kesel M, Hoyois B, Lobet Y, Hoet $\mathrm{P}$, et al. Simultaneous presence of different Borrelia burgdorferi genospecies in biological fluids of Lyme disease patients. J Clin Microbiol. 1995 Mar;33(3):602-8.

17. Liebisch G, Sohns B, Bautsch W. Detection and typing of Borrelia burgdorferi sensu lato in Ixodes ricinus ticks attached to human skin by PCR. J Clin Microbiol. 1998 Nov;36(11):3355-8.

18. Štěpánek P. Air temperature fluctuation in the Czech Republic of instrumental measurements [dissertation] [monograph on the Internet]. Brno: Faculty of Science, Masaryk University Brno; 2005 [cited 2009 Feb 25]. Available from: http://www.climahom.eu/software/docs/Disertace_PetrStepanek.pdf. (In Czech.)

19. Adamcová Z, Baláž P, Barščová S, Duhonský D, Hajný L, Halfar J, et al. Plan of care for the Landscape Protected Area Jeseníky in the period 2003 - 2013. Jeseník: Administration of Jeseníky PLA; 2003. (In Czech.)

20. Rauter C, Hartung T. Prevalence of Borrelia burgdorferi sensu lato genospecies in Ixodes ricinus ticks in Europe: a metaanalysis. Appl Environ Microbiol. 2005 Nov;71(11):7203-16.

21. Rijpkema S, Bruinink H. Detection of Borrelia burgdorferi sensu lato by PCR in questing Ixodes ricinus larvae from the Dutch North Sea island of Ameland. Exp Appl Acarol. 1996 Jul;20(7):381-5.

22. Kurtenbach K, Schäfer SM, De Michelis S, Etti S, Sewell HS. Borrelia burgdorferi sensu lato in the vertebrate host. In: Gray JS, Kahl O, Lane RS, Stanek G, editors. Lyme borreliosis: biology, epidemiology and control. New York: CABI Publishing; 2002. p. 117-48.

23. Danielová V, Daniel M, Schwarzová L, Materna J, Rudenko N, Golovchenko M, et al. Integration of a tick-borne encephalitis virus and Borrelia burgdorferi sensu lato into mountain ecosystems, following a shift in the altitudinal limit of distribution of their vector Ixodes ricinus (Krkonoše Mountains, Czech Republic). Vector Borne and Zoonotic Dis. In press 2009. 